\title{
Forign Ownership and Bank Performance: Evidence From Indonesia
}

\author{
Amarilla Hapsari, Rofikoh Rokhim
}

Faculty of Economics and Business, Universitas Indonesia, Depok, Indonesia

\section{Info Article}

History Article:

Received Desember 2016

Approved Februari 2017

Published Maret 2017

Keywords:

Banking; Foreign Ownership;

Indonesia.

\begin{abstract}
The main objective of this study is to examine the impact of foreign entry on the domestic banking market's profitability and overhead costs as financial sector FDI is a relatively new phenomenon and typically takes the form of banks in industrialized countries establishing branches and facilities in developing countries. A panel data covering the period from 2000 to 2012 is set based on the financial data from 82 commercial banks, which operated in Indonesia as of December 2012 and represented 92 percent of the commercial banks' total assets. The results of this study are expected to complement the existing collection of studies on the foreign penetration in the Indonesian banking industry, as to date there has been limited study of the impact of foreign ownership on bank performance in Indonesia. From a policy perspective, this study draws some conclusions which clarify the impacts of foreign penetration on banking industry. The government should continue to open the banking market up to foreign investors if they are proven to bring a positive impact, and should act conversely if they are proven to have an adverse impact on the local banking sector.
\end{abstract}

\section{Kepemilikan Asing dan Kinerja Bank: Kasus Indonesia}

\begin{abstract}
Abstrak
Tujuan utama dari penelitian ini adalah untuk menguji dampak dari masuknya bank asing pada profitabilitas pasar perbankan domestik dan biaya overhead dimana masuknya modal asing di sektor perbankan merupakan fenomena baru. Penelitian ini menggunakan panel data periode 2000-2012 dari data keuangan sejumlah 82 bank komersial, yang beroperasi di Indonesia pada Desember 2012 dan mewakili 92 persen dari total aset bank-bank komersial. Hasil dari penelitian ini dapat menjadi pelengkap bagi studi lain yang meneliti mengenai penetrasi asing pada sektor industri perbankan di Indonesia. Penelitian ini juga berkontribusi menambah pemahaman mengenai dampak dari kepemilikan asing terhadap peningkatan kinerja perbankan di Indonesia Dari kacamata pembuat kebijakan, studi ini memberikan kesimpulan yang dapat memperjelas dampak kepemilikan modal asing pada kinerja sektor perbankan. Pemerintah harus mendukung penetrasi asing pada sektor perbankan apabila memang memberikan dampakyang positif dan bersikap sebaliknya apabila penetrasi asing tidak memberikan manfaat yang nyata pada sektor perbankan Indonesia.
\end{abstract}

JEL Classification: G1, G21

Correspondence Address 
Amarilla Hapsari \& Rofikoh Rokhim / Forign Ownership and Bank Performance:...

\section{INTRODUCTION}

Many emerging countries have witnessed increased foreign banking activity in their banking sector in the last two decades. This increase in activity has been largely led by the privatization of state-owned banks and the rescue of distressed domestic financial institutions by multinational banks (Hryckiewicz \& Kowalewski, 2010). The share of foreign banks assets (measured as assets of foreign banks divided by total banking sector assets) in emerging Latin American and Asian countries increased from 26 percent in 1997 to 31 percent in 2008 . Meanwhile, the number of foreign-owned banks as of the total number of banks also increased from 37 percent to 42 percent during the same period (Jeon et al., 2011).

Other statistics show that the percentage of domestic banks among total banks in the developing world declined from 77 percent in 1995 to 62 percent in 2006, while the share of foreign-owned banks increased from 23 percent in 1995 to 38 percent in 2006 (Claessens, 2009). Today, more than 50 percent of banks have foreign owners in approximately 45 percent of developing countries.

Among many reasons, multinational banks enter foreign markets mainly to increase their profitability within an acceptable risk profile. The profitability and risk characteristics of a host country have been found to be important drivers of a banks decision to penetrate emerging markets. Banks prefer to maintain subsidiaries in countries where expected profits are large because of higher expected economic growth and the prospect of benefiting from local banks inefficiencies (Focarelli \& Pozzolo, 2005).

Foreign bank entry is often associated with spillover effects on domestic banks through their ownership-specific advantages and possession of proprietary technology on one hand, and through increase in competition on the other hand (Manlagñit, 2011). Similarly, the main objectives of liberalizing the Indonesian banking sector by the government is the spillover effects, which is expected to improve compe- tition in the banking industry and increase the bank profitability level, and thus help accelerate the countrys economic growth. In line with the Indonesian governments liberalization objectives, this paper focuses on examining whether foreign ownership in the country is associated with an increase in the profitability and a decrease in the overhead costs in the banking sector during the period of 2000-2012.This specified time period is chosen as foreign investors has shown their significant presence in the Indonesian banking sector since year 2000 .

The results of this study are expected to complement the existing collection of studies on the foreign penetration in the Indonesian banking industry, as to date there has been limited study of the impact of foreign ownership on bank performance in Indonesia. From a policy perspective, this study draws some conclusions which clarify the impacts of foreign penetration on banking industry. The government should continue to open the banking market up to foreign investors if they are proven to bring a positive impact, and should act conversely if they are proven to have an adverse impact on the local banking sector.

\section{Hypothesis Development}

Financial sector FDI is a relatively new phenomenon and typically takes the form of banks in industrialized countries establishing branches and facilities in developing countries (Goldberg, 2007). Today such ownership often exceeds 80 percent of local banking assets.

The FDI spillovers hypothesis (Hymer, 1960) states that foreign firms face significant disadvantages when compared with local competitors, with additional costs arising from cultural differences, legal barriers, or increased control problems, among others. Therefore, foreign firms must possess some firm-specific advantages to survive (Chen \& Liao, 2011). Commonly observed firm-specific advantages include superior production technologies and advanced management skills (Blomström et al., 2000). Other intangible advantages include, for example, brand name, trade mark or a reputa- 
tion for quality (Dunning, 1983). An important inference from this argument is that multinational corporations operating in a foreign country could generate productivity spillovers for the local industry through channels such as demonstration, personnel training, and competition (Blomström et al., 2000).

Goldbergs (2007) selective survey of the literature on FDI shows that FDI implications span evidence on technology transfer, productivity spillovers, wage effects, macroeconomic growth, and institutional development. Financial sector FDI is typically found to enhance the efficiency of banks that remain in business in the host markets. Efficiency calculations are performed by using data on overhead costs and bank net interest margin. Foreign banks operating in developing countries appear to be more efficient than their domestic counterparts, whether those counterparts are privately or governmentowned. Domestic banks are forced to become more efficient after foreign entry, especially in the business lines in which foreign banks choose to compete.

Meanwhile, the productivity and technology transfer arguments lead directly to the question of whether foreign entry benefits local workers in terms of wages. Studies of manufacturing industries link higher levels of foreign direct investment to higher wages (Goldberg, 2007). Studies based on bank balance-sheet data indicate that foreign bank operating costs are lower and that domestic bank costs are pushed down by foreign entry (Crystal et al., 2001). In some cases, wage expenditures also decline. However, the analysis has not determined whether these cost reductions are due to decreases in the number of workers (often a result of acquisitions and consolidations of banks) without wage declines or to reductions in employment with higher wages paid to the remaining workers.

In relation to macroeconomic growth, studies of financial sector FDI effects conclude that growth may expand both through the technology transfer channel and through improved intermediation of capital flows between savers and investment opportunities. Positive growth effects from financial sector FDI can occur because of more efficient credit allocation in host markets, with funds made more available for the private sector (Goldberg, 2007). Prior to financial sector liberalization and reform, some governments used the local banking system as a tool for providing directed credit to politically favored constituents or favored but loss-incurring sectors of the economy.

In conclusion, Crystal et al. (2001) show that foreign-owned banks appear to contribute to the overall soundness of local banking systems by screening and treating problem loans more aggressively. If foreign entry spurs additional regulatory improvements, the risk of financial crisis declines. Williams and Nguyen (2005) supported bank privatization and the repeal of state ownership on economic grounds. They suggested the potential benefits of foreign ownership may take longer to be realized. Bayyurt (2013) showed that domestic banks have less performance than the foreign owned banks on average.

Nagano (2016) showed that a bank is more likely to reduce its risk appetite and improve its operational cost efficiency as its foreign ownership ratio increases, regardless of the banks lending partner. Berger and Hannan (1989) showed that banks with foreign ownership (both majority and minority ownership) and banks with conglomerate affiliation are associated with fewer diseconomies of diversification, suggesting that foreign ownership and conglomerate affiliation may play important mitigating roles. Mishkin (2005) argues that financial globalization should be an important supporting force behind institutional reform. $\mathrm{He}$ contends that domestic institutions, facing competition from abroad, will seek new customers to stay in business. For lending to be profitable, domestic banks will require information to screen and monitor their customers.

Better accounting standards and disclosure requirements, as well as a more efficiently managed legal system, will be consistent with continued domestic bank profitability. Foreign-owned banks will also be a constituency 
Amarilla Hapsari \& Rofikoh Rokhim / Forign Ownership and Bank Performance:...

supporting these positive reforms because, as outsiders, they will not have access to the same information as their domestic competitors. $\mathrm{Nu}$ merous studies assert that financial sector FDI spurs improvements in bank supervision, with regulatory spillovers (Goldberg, 2007).

\section{METHOD}

Using a similar method to that of Manlagñit (2011), the main objective of his study is to examine the effects of foreign entry by focusing on two possible channels through which foreign entry may influence the domestic banking market: (i) spillovers which are associated with increase profitability and a decrease in overhead costs; and (ii) competition which causes a reduction in both profitability and overhead costs. To examine the impact of foreign ownership on the domestic bank's performance, the following regression model is used:

$$
\text { Bank Performance }_{\text {it }}=\alpha+\beta \text { FS }_{\text {it }}+\gamma \mathrm{B}_{\mathrm{it}}+\varepsilon
$$

Where Bank Performance ${ }_{i t}$ refers to indicators of bank performance for domestic banks $i$ at time $t_{;} \mathrm{FS}_{t}$ is the share of foreign-owned banks at time $t ; B_{i t}$ refers to bank variables for domestic banks $i$ at time $t ; \alpha, \beta$, and $\gamma$ are vectors of regression coefficients; and $\varepsilon_{i t}$ is an error term, which is assumed to be a normally distributed random variable. The effect of foreign entry is captured by the coefficient $\beta$, which is estimated using foreign-owned bank indicators.

There is no lag of time $t$ between the performance indicators (Bank Performance) and foreign presence indicators (FS) due to the unique characteristics of banking business. When foreign investors inject an additional capital to a bank, it will be directly reflected in the bank's financial performance, for example in terms of bank's CAR level. The bank will utilize right away the money to create profitability, by lending it to the customers, or to improve its productivity by investing it in technology or product innovation. The results of this utilization will be reflected in the bank's financial perfor- mance, for example in terms of ROA, NIM, or bank's overhead cost ratio.

This study uses financial data from 82 commercial banks which operated in Indonesia as of December 2012 and represented 92 percent of the commercial banks' total assets. The financial data covers the period from 2000 to 2012, and was obtained from individual commercial banks' annual balance sheets and income statements from the BI website. The financial data for the year 2012 is proxied using the financial data of September 2012, as by the time this study was conducted, the financial data of December 2012 had not yet been published on the BI website. In total, the panel data consists of 1,066 observations.

The dependent variable which measured by bank performance is profitability and the overhead costs of the banks. To measure bank profitability, a profitability indicator, which is calculated as the ratio of before-tax profits to total assets (or ROA), is used. Micco et al. (2007) in their research, which covers 50,000 observations in 119 countries, use ROA as a standard indicator of bank performance. The formula to calculate ROA is:

$$
\text { Return of assets }(\mathrm{ROA})=\frac{\text { Net income }}{\text { Total assets }}
$$

The other dependent variable is the overhead costs, which are commonly used to measure the efficiency of banks in managing their expenses. Manlagñit (2011) defines overhead costs as the ratio of non-interest expenses, consisting of personnel expenses, premises, and equipment expenses, fees and service expenses, and other non-interest expenses, to total assets. Berger et al. (2000) suggest that, rather than using a total cost function; overhead costs have been shown to comprise the bulk of the cost inefficiency of banks and are substantially influenced by the local market power of a bank. This study, similarly to Manlagñit (2011), measures efficiency using the overhead cost ratio, which is calculated as the ratio of operating expenses to total assets. 
Overhead cost ratio $=\frac{\text { Total operating expenses }}{\text { Total assets }}$

Following Manlagñit (2011), two measures of foreign ownership presence are used in this study: (i) the ratio of the number of foreignowned banks to the total number of banks in the commercial banking system; and (ii) the share of foreign-owned bank assets in the total commercial banking assets. Claessens et al. (2001) suggest that the number of foreign banks is suitable to measure the foreign ownership presence if the number of domestic and foreign-owned banks determines competitive conditions. For instance, in order to prevent foreign banks from capturing a substantial market share, domestic banks adjust their pricing for lending and other services as soon as a foreign presence enters the local market.

Manlagñit (2011), however, has a different view. According to him, the above may only happen if the share of foreign-owned banks is large enough to cause significant pressure on the domestic banking market.

Following Rokhim and Susanto (2013), the foreign-owned banks in this study can be described as follows; Branches or subsidiaries of foreign banks with headquarters overseas. Examples include: the Bank of America, Deutsche Bank AG, the Bangkok Bank, and the Bank of Tokyo Mitsubishi UFJ. Banks with single foreign ownership which accounts for more than 10 percent of the total stake. Examples include: Bank Danamon, Bank OCBC NISP, and Bank CIMB Niaga. Banks with several foreign ownerships which, if being added together, accounts for more than 10 percent of the total stake. Examples include: The Bank of India Indonesia and Bank Mayapada International.

It is necessary to control for other determinants of domestic banks' performance in order to analyze the spillover effects of foreign entry on domestic banks' performance. Following Manlagñit (2011), the set of variables that controls for bank-specific characteristics inclu-

Table 1.Lists of Dependent and Independent Variables

\begin{tabular}{|c|c|c|}
\hline Variables & Description & Symbols \\
\hline \multicolumn{3}{|l|}{ Dependent Variables } \\
\hline Profitability & Ratio of net income to total assets (ROA) & $\mathrm{ROA}$ \\
\hline Overhead cost ratio & Ratio of operating expenses to total assets & Cost \\
\hline \multicolumn{3}{|l|}{ Independent Variables } \\
\hline \multicolumn{3}{|l|}{ Foreign Ownership Indicators } \\
\hline Foreign number & $\begin{array}{l}\text { Ratio of number of foreign-owned banks to the } \\
\text { total number of banks in the commercial banking } \\
\text { system }\end{array}$ & FS1 \\
\hline Foreign share & $\begin{array}{l}\text { Ratio of foreign-owned bank assets to the total } \\
\text { commercial banking assets }\end{array}$ & FS2 \\
\hline \multicolumn{3}{|l|}{ Bank Variables } \\
\hline Equity ratio & Ratio of total equity to total assets & Equity \\
\hline Loans-to-asset ratio & Ratio of loans to total assets & $L A$ \\
\hline Customer funding ratio & Ratio of total deposits to total assets & Funding \\
\hline Market share ratio & $\begin{array}{l}\text { Ratio of total assets of the bank to the total com- } \\
\text { mercial banking assets }\end{array}$ & MS \\
\hline Loan loss provision ratio & Ratio of loan loss provisions to total loans & $L L$ \\
\hline Market concentration ratio & $\begin{array}{l}\text { Ratio of assets of the five largest banks to the total } \\
\text { commercial banking assets }\end{array}$ & $M C$ \\
\hline
\end{tabular}


Amarilla Hapsari \& Rofikoh Rokhim / Forign Ownership and Bank Performance:...

des: (i) equity; (ii) the ratio of loans-to-assets; (iii) customer funding; (iv) market share; (v) loan loss provision; and (vi) degree of asset market concentration. Table 1 below summarizes all variables used in the estimation.

\section{RESULT AND DISCUSSION}

The first form of analysis of the data sample uses the descriptive statistics to describe the basic features of the data in this study. They provide simple summaries of the sample and the measures such as mean, median, minimum, maximum, and standard deviations.

Table 2 presents the descriptive statistics of both dependent and independent variables in the model. The dependent variables include profitability (ROA) and overhead cost ratio (Cost), while the independent variables include foreign ownership indicators (FS1 and FS2), and bank specific variables (equity-to-asset ratio (Equity), loans-to-asset ratios (LA), customer funding ratios (Funding), market shares (MS), loan loss provision ratios (LL), and market concentration (MC).

The Jarque-Bera test, a goodness-of-fit test of whether sample data have the skewness and kurtosis to match a null hypothesis of a normal distribution, is used to examine if sample data has a normal distribution. The results from the Jarque-Bera test show small probability values, leading to the rejection of the null hypothesis of normal distribution.
Table 4 and Table 5 present the result of the estimation using a fixed effects model. A fixed effects model is preferred over a random effects model based on the Hausman specification test. The Hausman specification test is used to compare approaches between random effects and fixed effects estimators, under the null hypothesis that the random effects estimator is correct. The Hausman test shows that there are no cross-section effects as indicated by the estimators of the cross-section effects.

The F-statistics computes the standard F-test of the joint hypothesis that all the coefficients, except the intercept (C), equal zero. The probability of F-statistics which displays the p-value corresponding to the reported Fstatistics is equal to 0.0000 , meaning that there is no chance at all that the coefficients of the independent variable would all equal zero.

The Durbin-Watson (DW) statistics examine the phenomenon of multicollinearity, which occurs when two or more independent variables (or regressors) in the model are correlated and provide redundant information about the response. High multicollinearity will increase the standard of errors of estimates and result in confusing and misleading results. The DW statistics show that there is no evidence of serial correlation.

The model estimation is conducted in two stages. The first stage involves all the panel data sample and the results are shown in the third column of Table 4 and Table 5 (e.g. co-

Table 2. Descriptive Statistics of Dependent and Independent Variables

\begin{tabular}{lllllllllll}
\hline & ROA & COST & FS1 & FS2 & EQUITY & LA & FUNDING & MS & LL \\
\hline Mean & $2.05 \%$ & $4.29 \%$ & 36.85 & $38.97 \%$ & $14.23 \%$ & $55.96 \%$ & $72.45 \%$ & $1.11 \%$ & $1.24 \%$ & $54.51 \%$ \\
Median & $1.87 \%$ & $3.60 \%$ & 35.00 & $42.92 \%$ & $11.27 \%$ & $59.35 \%$ & $77.67 \%$ & $0.15 \%$ & $0.49 \%$ & $52.43 \%$ \\
Max. & $36.86 \%$ & $93.63 \%$ & 43.00 & $51.64 \%$ & $97.86 \%$ & $185.57 \%$ & $93.94 \%$ & $25.91 \%$ & $283.62 \%$ & $62.40 \%$ \\
Min. & $-152.99 \%$ & $0.19 \%$ & 29.00 & $14.60 \%$ & $-27.49 \%$ & $0.55 \%$ & $3.04 \%$ & $0.00 \%$ & $-154.90 \%$ & $49.42 \%$ \\
Std. Dev. & $5.89 \%$ & $4.69 \%$ & 4.59 & $9.98 \%$ & $11.38 \%$ & $20.07 \%$ & $16.91 \%$ & $2.85 \%$ & $12.56 \%$ & $4.49 \%$ \\
Skewness & -17.64 & 10.52 & -0.19 & -1.19 & 2.58 & 0.14 & -1.52 & 4.52 & 9.37 \\
Kurtosis & 460.17 & 160.31 & 1.71 & 3.42 & 15.24 & 6.64 & 5.37 & 26.76 & 289.29 \\
Jarque-Bera & $9,338,626$ & $1,118,859$ & 81 & 261 & 7,832 & 593 & 659 & 1.57 & 28,716 & $3,655,961$ \\
Prob. & 0.00 & 0.00 & 0.00 & 0.00 & 0.00 & 0.00 & 0.00 & 123 & 0.00 & 0.00 \\
Obs. & 1,066 & 1,066 & 1,066 & 1,066 & 1,066 & 1,066 & 1,066 & 1,066 & 1,066 \\
\hline
\end{tabular}


lumn with heading: "All”). The second stage of estimation is performed on a pool basis, with each pool being composed of banks which are categorized according to their "BUKU" types. In January 2013

BI issued the Banking Act No. 14/26/ $\mathrm{PBI} / 2012$ ("Regulation 14B") on the business activities and branch or office networks of banks. According to Regulation 14B, banks are categorized into four types, called "BUKU" categories, based on the amount of their core capital. Regulation 14B, along with other recent initiatives by BI, demonstrated BI's intention to bolster the country's banking sector by promoting capital strengthening, banking consolidation, and improvement of governance.

The category into which a bank falls determines the scope of business activities it is permitted to carry out, including the possibility of whether it can make investments. Any restrictions applied to the investments made are also taken into account. For example, banks that are classified as BUKU 1 can only carry out basic banking activities such as deposit taking and lending of funds in IDR. They are not entitled to invest their capital in other financial institutions and can only deal with a limited range of banking products in IDR. Meanwhile banks in BUKU 2, BUKU 3, and BUKU 4 categories are permitted to carry out banking activities in IDR and foreign currency, and to make capital investments.

The results of the second stage estimation are shown in the fourth, fifth, sixth, and seventh column of Table 4 and Table 5 (e.g. columns with headings: "BUKU 1", "BUKU 2", "BUKU 3", and "BUKU 4", respectively).

The results from the estimation show that both the number of foreign-owned banks (FS1) and the asset share of foreign-owned banks (FS2) consistently have a positive and significant impact on the profitability and overhead costs of domestic banks (although this is not significant in several estimations using "BUKU" classification). Both FS1 and FS2 estimations are statistically significant for regression models using all data panel. However, the estimation result of FS1 for ROA is not statistically significant for a regression model using a "BUKU 4" classification.

The estimation results of FS2 for ROA are statistically significant for regression models using "BUKU 3" and "BUKU 4" classifications. The estimation results of FS1 for Cost are statistically significant for regression models using "BUKU 1" and "BUKU 4" classifications, and the estimation result of FS2 for Cost is not statistically significant for a regression model using a "BUKU 2" classification. Several observations can be made about these findings.

Firstly, these results indicate that a foreign-owned bank presence can improve the profitability of the Indonesian domestic banking market. The above finding, although it is different from Manlagñit (2011), is consistent with Micco et al. (2007) and Lu et al. (2009), Manlagñit examines the economic effects of the liberalization of foreign bank entry in the Philippines from 1990 to 2006 and finds strong evidence of the dominance of competition effects because of the presence of foreign banks, which leads to a reduction in the profitability and overhead costs of domestic commercial banks.

Micco et al. (2007) conducted a research consisting of 50,000 observations in 119 countries, and establish that ownership is strongly correlated with bank performance, especially in

Table 3. BUKU Category under Banking Act No. 14/26/PBI/2012

\begin{tabular}{ll}
\hline Category & Core Capital Value of Banks \\
\hline BUKU 1 & < IDR 1 trillion \\
BUKU 2 & IDR 1 trillion $-<$ IDR 5 trillion \\
BUKU 3 & IDR 5 trillion $-<$ IDR 30 trillion \\
BUKU 4 & At least IDR 30 trillion \\
\hline
\end{tabular}

Source: Bank Indonesia (www.bi.go.id) 
Amarilla Hapsari \& Rofikoh Rokhim / Forign Ownership and Bank Performance:...

Table 4. Regression Results Using Fixed Effects Model-ROA (2000-2012)

\begin{tabular}{|c|c|c|c|c|c|c|}
\hline & & \multicolumn{5}{|c|}{ Profitability (ROA) } \\
\hline & & All & Buku 1 & Buku 2 & Buku 3 & Buku 4 \\
\hline Intercept & $C$ & $\begin{array}{l}0.029^{* * *} \\
(0.007)\end{array}$ & $\begin{array}{l}0.027^{* *} \\
(0.013)\end{array}$ & $\begin{array}{l}0.046^{* * *} \\
(0.013)\end{array}$ & $\begin{array}{l}-0.006 \\
(0.020)\end{array}$ & $\begin{array}{l}0.193^{* *} \\
(0.076)\end{array}$ \\
\hline \multicolumn{7}{|l|}{ Foreign Ownership Indicators } \\
\hline Foreign-owned bank number & FS1 & $\begin{array}{l}0.001^{* * *} \\
0.000\end{array}$ & $\begin{array}{l}0.000 \text { ** } \\
0.000\end{array}$ & $\begin{array}{l}0.001^{* * *} \\
0.000\end{array}$ & $\begin{array}{l}0.001 \\
0.000\end{array}$ & $\begin{array}{l}0.000 \\
(0.001)\end{array}$ \\
\hline Foreign-owned bank asset share & FS2 & $\begin{array}{l}0.013^{* *} \\
(0.005)\end{array}$ & $\begin{array}{l}0.003 \\
(0.008)\end{array}$ & $\begin{array}{l}0.001 \\
(0.011)\end{array}$ & $\begin{array}{l}0.032^{* *} \\
(0.016)\end{array}$ & $\begin{array}{l}0.061^{*} \\
(0.035)\end{array}$ \\
\hline \multicolumn{7}{|l|}{ Bank Variables } \\
\hline Equity ratio & Equity & $\begin{array}{l}0.067^{* * *} \\
(0.008)\end{array}$ & $\begin{array}{l}-0.009 \\
(0.012)\end{array}$ & $\begin{array}{l}0.144^{* * *} \\
(0.017)\end{array}$ & $\begin{array}{l}0.063 * \\
(0.035)\end{array}$ & $\begin{array}{l}0.011 \\
(0.128)\end{array}$ \\
\hline Loans-to-asset ratio & $L A$ & $\begin{array}{l}0.013^{* * *} \\
(0.003)\end{array}$ & $\begin{array}{l}0.008^{* *} \\
(0.004)\end{array}$ & $\begin{array}{l}0.015^{* *} \\
(0.006)\end{array}$ & $\begin{array}{l}0.041^{* * *} \\
(0.009)\end{array}$ & $\begin{array}{l}0.003 \\
(0.036)\end{array}$ \\
\hline Customer funding ratio & Funding & $\begin{array}{l}-0.003 \\
(0.005)\end{array}$ & $\begin{array}{l}-0.006 \\
(0.009)\end{array}$ & $\begin{array}{l}-0.005 \\
(0.007)\end{array}$ & $\begin{array}{l}0.018 \\
(0.013)\end{array}$ & $\begin{array}{l}-0.196 \text { ** } \\
(0.079)\end{array}$ \\
\hline Overhead Costs & Cost & $\begin{array}{l}-0.061 \text { *** } \\
(0.017)\end{array}$ & $\begin{array}{l}-0.027 \\
(0.029)\end{array}$ & $\begin{array}{l}-0.101^{* * *} \\
(0.032)\end{array}$ & $\begin{array}{l}-0.047 \\
(0.049)\end{array}$ & $\begin{array}{l}-0.216 \\
(0.277)\end{array}$ \\
\hline Market share ratio & MS & $\begin{array}{l}-0.092 * \\
(0.055)\end{array}$ & $\begin{array}{l}-0.452 \\
(1.039)\end{array}$ & $\begin{array}{l}0.722^{* *} \\
(0.285)\end{array}$ & $\begin{array}{l}0.037 \\
(0.170)\end{array}$ & $\begin{array}{l}-0.291 \text { ** } \\
(0.132)\end{array}$ \\
\hline Loan loss provision ratio & $L L$ & $\begin{array}{l}-0.027^{* * *} \\
(0.007)\end{array}$ & $\begin{array}{l}-0.018 * \\
(0.009)\end{array}$ & $\begin{array}{l}-0.017^{*} \\
0.009\end{array}$ & $\begin{array}{l}-0.255^{* * *} \\
(0.024)\end{array}$ & $\begin{array}{l}0.018 \\
(0.060)\end{array}$ \\
\hline Market concentration ratio & $M C$ & $\begin{array}{l}0.007 \\
(0.007)\end{array}$ & $\begin{array}{l}0.011 \\
(0.010)\end{array}$ & $\begin{array}{l}-0.012 \\
(0.014)\end{array}$ & $\begin{array}{l}0.013 \\
(0.021)\end{array}$ & $\begin{array}{l}0.052 \\
(0.039)\end{array}$ \\
\hline Total panel (balanced) observations & & 1,066 & 520 & 325 & 169 & 52 \\
\hline R-squared & & 0.6790 & 0.5684 & 0.7278 & 0.7653 & 0.6389 \\
\hline S.E. of regression & & 0.0528 & 0.0240 & 0.0798 & 0.0122 & 0.0137 \\
\hline F-statistics & & 22.9123 & 12.9223 & 23.5784 & 22.8262 & 5.7497 \\
\hline Prob (F-statistics) & & 0.0000 & 0.0000 & 0.0000 & 0.0000 & 0.0000 \\
\hline
\end{tabular}

Note: Panel least squares method is used; ${ }^{*}, *$, and ${ }^{* * *}$ statistically significant at the $10 \%, 5 \%$, and $1 \%$ levels, respectively; standard errors are given in parentheses

developing countries. Meanwhile in China, $\mathrm{Lu}$ et al. (2009) investigated the influence of foreign-owned banks on local bank performance and find that the liberalization of China's commercial banking sector has clearly been effective in increasing banks' profitability.

Secondly, the positive impact of the number and the asset share of foreign-owned banks on profitability and overhead costs indicate that, following the entry of foreign investors in the domestic banking market, both the revenues and overhead costs of domestic commercial banks increase. These findings suggest that when there is a foreign presence in the bank's ownership structure, this bank might train its employees to enhance their human capital and invest heavily in technology, product innovation, and branch networks in order to introduce cutting-edge banking technology, new banking products, and to expand the bank's reach to enter into untapped segments, thus resulting in improving bank profitability and increasing overhead costs.

These expenses, however, might be further ofFSet by the beneficial effects in the long run and result in greater efficiency of domestic banks, as Claessens et al. (2001) state that an increased foreign presence compels domestic banks to give up their sheltered "quite life" and place a greater focus on cost efficiency. 
Table 5. Regression Results Using Fixed Effects Model-Cost (2000-2012)

\begin{tabular}{|c|c|c|c|c|c|c|}
\hline & & \multicolumn{5}{|c|}{ Overhead Costs (Cost) } \\
\hline & & All & Buku 1 & Buku 2 & Buku 3 & Buku 4 \\
\hline Intercept & $C$ & $\begin{array}{l}0.025^{* * *} \\
(0.006)\end{array}$ & $\begin{array}{l}0.026^{*} \\
(0.013)\end{array}$ & $\begin{array}{l}0.012 \\
(0.014)\end{array}$ & $\begin{array}{l}0.028 * \\
(0.015)\end{array}$ & $\begin{array}{l}0.102^{* * *} \\
(0.033)\end{array}$ \\
\hline \multicolumn{7}{|l|}{ Foreign Ownership Indicators } \\
\hline Foreign-ow ned bank number & FS1 & $\begin{array}{l}0.000^{* * *} \\
0.000\end{array}$ & $\begin{array}{l}0.001^{* * *} \\
0.000\end{array}$ & $\begin{array}{l}0.000 \\
0.000\end{array}$ & $\begin{array}{l}0.000 \\
0.000\end{array}$ & $\begin{array}{l}0.001^{* *} \\
0.000\end{array}$ \\
\hline Foreign-ow ned bank asset share & FS2 & $\begin{array}{l}0.030^{* * *} \\
(0.005)\end{array}$ & $\begin{array}{l}0.051^{* * *} \\
(0.008)\end{array}$ & $\begin{array}{l}0.008 \\
(0.011)\end{array}$ & $\begin{array}{l}0.043^{* * *} \\
(0.011)\end{array}$ & $\begin{array}{l}0.046^{* *} \\
(0.019)\end{array}$ \\
\hline \multicolumn{7}{|l|}{ Bank Variables } \\
\hline Equity ratio & Equity & $\begin{array}{l}0.036^{* * *} \\
(0.007)\end{array}$ & $\begin{array}{l}0.042^{* * *} \\
(0.014)\end{array}$ & $\begin{array}{l}0.056^{* * *} \\
(0.013)\end{array}$ & $\begin{array}{l}0.041 * \\
(0.023)\end{array}$ & $\begin{array}{l}-0.040 \\
(0.068)\end{array}$ \\
\hline Loans-to-asset ratio & $L A$ & $\begin{array}{l}0.013^{* * *} \\
(0.002)\end{array}$ & $\begin{array}{l}0.007 * \\
(0.004)\end{array}$ & $\begin{array}{l}0.019^{* * *} \\
(0.006)\end{array}$ & $\begin{array}{l}-0.010 * \\
(0.006)\end{array}$ & $\begin{array}{l}0.037^{*} \\
(0.020)\end{array}$ \\
\hline Customer funding ratio & Funding & $\begin{array}{l}0.001 \\
(0.004)\end{array}$ & $\begin{array}{l}0.017 \\
(0.011)\end{array}$ & $\begin{array}{l}0.008 \\
(0.007)\end{array}$ & $\begin{array}{l}-0.009 \\
(0.012)\end{array}$ & $\begin{array}{l}-0.066 * \\
(0.038)\end{array}$ \\
\hline Overhead Costs & Cost & & & & & \\
\hline Market share ratio & $M S$ & $\begin{array}{l}-0.180^{* * *} \\
(0.045)\end{array}$ & $\begin{array}{l}-3.756^{* * *} \\
(1.114)\end{array}$ & $\begin{array}{l}-0.543 \\
(0.383)\end{array}$ & $\begin{array}{l}-0.389^{* * *} \\
(0.108)\end{array}$ & $\begin{array}{l}-0.110^{* *} \\
(0.052)\end{array}$ \\
\hline Loan loss provision ratio & $L L$ & $\begin{array}{l}0.001 \\
(0.004)\end{array}$ & $\begin{array}{l}-0.008 \\
(0.006)\end{array}$ & $\begin{array}{l}0.002 \\
(0.005)\end{array}$ & $\begin{array}{l}0.026^{* *} \\
(0.013)\end{array}$ & $\begin{array}{l}-0.046 \\
(0.034)\end{array}$ \\
\hline Market concentration ratio & $M C$ & $\begin{array}{l}0.010 \\
(0.006)\end{array}$ & $\begin{array}{l}0.009 \\
(0.009)\end{array}$ & $\begin{array}{l}0.007 \\
(0.015)\end{array}$ & $\begin{array}{l}-0.004 \\
(0.015) \\
\end{array}$ & $\begin{array}{l}0.030 \\
(0.021)\end{array}$ \\
\hline Total panel (balanced) observations & & 1,066 & 520 & 325 & 169 & 52 \\
\hline R-squared & & 0.7208 & 0.6601 & 0.6292 & 0.7279 & 0.7712 \\
\hline S.E. of regression & & 0.0379 & 0.0394 & 0.0340 & 0.0161 & 0.0058 \\
\hline F-statistics & & 28.3179 & 19.5034 & 15.4866 & 19.7983 & 12.2576 \\
\hline Prob (F-statistics) & & 0.0000 & 0.0000 & 0.0000 & 0.0000 & 0.0000 \\
\hline
\end{tabular}

Note: Panel least squares method is used; ${ }^{*},{ }^{* *}$, and ${ }^{* * *}$ statistically significant at the $10 \%, 5 \%$, and $1 \%$ levels, respectively; standard errors are given in parentheses

Taken as a whole, the findings provide evidence that foreign entry is associated with improved domestic banking performance. Specifically, the entry of foreign investors in the domestic banking market may serve as an effective competitive force, forcing domestic banks to enhance and expand their business in order to increase their profitability as well as compelling domestic banks to update production technology and techniques.

The bank variables included in the regression model affect profitability and overhead costs, generally in ways that can be explained. The first bank variable is the equity ratio (Equity), which is defined as the ratio of equity to total assets. The results of the estimation show that Equity has a positive and statistically significant impact on profitability and overhead costs (only the equity ratio in the estimations using "BUKU 1" and "BUKU 4" classifications have a negative and not statistically significant impact on profitability and overhead costs, respectively). This conclusion supports the argument that well-capitalized banks, as indicated by high equity ratio, perform better in terms of profitability mainly due to their access to cheaper sources of funds, high quality management, and cautious risk-taking behavior.

The level of equity in a bank indicates the supplies of long-term money needed to get a 
new financial institution started, provides a base for future growth, and promotes public confidence. Mester (1996) suggest that an equity ratio measures the asset quality of the banks, and takes into account their differences in risk preferences. Rao (2005) finds that the level of equity is fundamentally linked to the bank's risk management and risk signaling. Moreover, Berger and Hannan (1989) concludes that wellcapitalized banks enjoy access to cheaper sources of funds with a subsequent improvement in profit rates.

The second bank variable is the ratio of loans-to-assets (LA), which captures the output mix of the bank. In all estimations, the loans-toasset ratio has a positive and statistically significant impact on profitability and overhead costs (only the loans-to-asset ratio in the regression model using "BUKU 3" classification has a negative and statistically significant impact on overhead costs). These findings suggest that banks with higher loans-to-asset ratio tend to have higher profitability as higher ratios mean less liquidity and more bank assets are tied up in loans.

Liquid assets are associated with lower rates of return. However, on the other hand, loans are more costly to produce than investment securities, thus it is expected that a high ratio of loans-to-asset ratio is positively associated with the overhead costs of the banks.

The third bank variable is customer funding (Funding). The estimation results show a mixed of negative and positive impacts on both profitability and overhead costs, and therefore, are inconclusive. The customer funding ratio for the regression model using "BUKU 4" classification is the only one with a statistical significant impact on both profitability and overhead costs.

The fourth bank variable is the overhead costs (Cost), which, as predicted, has a negative and statistically significant impact on profitability. It is self-explanatory that the higher the ratio of overhead costs to total assets, the lower the profitability level of the banks. According to Berger et al. (2000), overhead costs have been shown to comprise the bulk of cost inefficiency of banks and are substantially influenced by the local market power of the banks.

The fifth bank variable is the bank's market share (MS), which consistently shows a negative and significant relationship with overhead costs, though its relationship to profitability is inconclusive as there is a mixed result of negative and positive impact on bank profitability. This finding suggests that a bank's size may affect its performance. Boyd and Runkle (1993) suggest that large banks may have lower cost of gathering and processing information due to economies of scale. Similarly, according to Smirlock (1985), large banks enjoy higher profits from loan and product diversification and access into markets to which smaller banks have no access due to economies of scope.

The sixth bank variable is the loan loss provision ratio (LL), as an indicator of the bank's asset quality. The estimation results show that LL has a negative and statistically significant impact on bank profitability. This finding suggests that banks with high nonperforming loans, and therefore incur high loan loss provisions, have a lower profitability level. An increasing trend in the ratio of nonperforming loans to total loans signals a deterioration in the quality of credit portfolios and, consequently, in financial institutions' cash flows, net income, and solvency, so it is important to monitor the level of nonperforming loans.

The effect of LL to overhead costs, however, is inconclusive as it is a mixture of negative and positive impacts, with only one estimation has a statistically significant impact. This finding, however, can be explained as loan loss provision is not included in the calculation of overhead costs. The variable of overhead costs used in the regression model only covers operating expenses such as general and administration cost, employee salary, and promotion expenses.

The seventh and last bank variable is the market concentration (MC), which is an indicator of market structure and scale effects. The estimation results show that $M C$ has a positive impact to both profitability and overhead costs, 
though this is not statistically significant. This finding suggests that market concentration does not appear to explain the changes in the profitability and overhead costs of domestic banks.

\section{CONCLUSIONAND RECOMMENDATION}

It can be concluded from the analysis that foreign ownership is associated with an increase in the profitability of the Indonesian domestic banks. This finding suggests that the presence of foreign-owned bank can improve the profitability of the Indonesian domestic banking market, a finding which is different from Manlagñit (2011) but consistent with Micco et al. (2007) and $\mathrm{Lu}$ et al.(2009). Micco et al. (2007) find from their study, covering 50,000 observations in 119 countries, that ownership is strongly correlated with bank performance, especially in developing countries.

Meanwhile in China, Lu et al.(2009) investigated the influence of foreign-owned banks on the local bank performance and find that the liberalization of China's commercial banking sector has clearly been effective in increasing banks' profitability.

In relation to the overhead costs, it can be concluded that foreign ownership is associated with an increase in the overhead costs of the Indonesian domestic banks. This finding suggests that when there is a foreign presence in the bank's ownership structure, this bank might train its employees to enhance their human capital and invest heavily in technology, product innovation, and branch networks in order to introduce cutting-edge banking technology, new banking products, and to expand the bank's reach to enter into untapped segments, thus resulting in improving bank profitability and increasing overhead costs.

These expenses, however, might be further ofFSet by the beneficial effects in the long run and result in greater efficiency of domestic banks, as Claessens and Laeven (2004) state that the increased foreign presence compels domestic banks to give up their sheltered "quite life" and place a greater focus on cost efficiency.
Furthermore, based on the analysis presented in previous section, this study also noted that both the ratio of the number of foreignowned banks to the total number of banks in the commercial banking system (FS1) and the ratio of foreign-owned bank assets to the commercial banks' total assets (FS2) have shown trends towards increases over time, indicating that foreign ownerships in terms of number of banks and share of bank assets have expanded in the Indonesian commercial banking market.

The number of banks with foreign ownerships was only 29 in 2000, but now it has reached up to 43 (as of September, 2012). Similarly, as of December, 2000, the share of foreignowned bank assets was 14.6 percent, but now it has grown threefold, reaching 44.6 percent of the commercial banks' total assets.

Taken as a whole, the findings provide evidence that foreign entry is associated with improved domestic banking performance. Specifically, the entry of foreign investors in the domestic banking market may serve as an effective competitive force, forcing domestic banks to enhance and expand their business in order to increase their profitability as well as compelling domestic banks to update production technology and techniques. Based on the results of this study, there are recommendations to the related parties that may benefit from this study.

For academicians, it is suggested that academicians conduct further study, such as qualitative assessment, to validate the results of this research. Current studies on foreign presences in the banking sector have focused heavily on the quantitative and statistical approaches. Thus, qualitative approach, such as interviews with major bank players especially those with foreign shareholders and benchmarking studies between local banks and foreign-owned banks, will further help explain the economic effects of foreign bank presence in the country.

For policy makers, the findings from this study provide evidence that foreign entry is associated with improved domestic banking performance, thus supporting the ongoing bank ownership reform in Indonesia. However, fi- 
Amarilla Hapsari \& Rofikoh Rokhim / Forign Ownership and Bank Performance:...

nancial sector FDI may cause excess risk as foreign-owned banks may try to build market share by offering a variety of new financial products, including over-the-counter derivatives, structured notes, and equity swaps. One clear implication is that local banking supervisors need to continuously invest in upgrading their skills to strengthen domestic prudent regulation and supervision on the commercial banking system.

As Chen and Liao (2011) stated in her study that an even more open banking sector should also be monitored and regulated to ensure efficient and healthy banking sector that contributes to the development of the economy and welfare of the society.

For the banking industry, this study helps practitioners in the banking industry identify the influence of foreign penetration on banklevel performance. It is important to understand the impact of foreign investors on the banking industry, so that practitioners in the banking sector are able to seek ways to improve their existing cooperation with foreign investors.

For investors, the results of this study justify the liberalization of foreign entry in the Indonesian banking sector. However, it is important to note that this study is based on the observation in a banking environment in which banking sector is closely monitored and properly regulated. It is imperative to make a distinction between financial liberalization and banking regulation.

As Chen and Liao (2011) stated in her study that a more open banking sector does not mean a banking sector free of regulation. The presence of foreign investors in the Indonesian banking sector are appreciated, however they have to fully support domestic prudent banking regulation to ensure healthy banking sector that could contribute to the development of the local economy.

Future research needs to include qualitative assessment on the impact of foreign entry on the domestic banking market to validate the results of this study. For example, interviews with major bank players, especially those with foreign shareholders, will further help explain the economic effects of foreign bank presence in the country. It would also be important to take into consideration the entry of nonbank financial institutions, such as multi-finance companies, in the country and its effects on the efficiency and competitiveness of the financial system in general.

At the same time, to further understand the behavior of foreign-owned banks in the country, it would be relevant for the analysis to include the conditions of the parent companies that could possibly affect the performance of foreign-owned banks. Chen and Liao (2011) find that there are home- and host-country effects of banking market structure and macroeconomic condition on foreign bank performances.

\section{REFERENCES}

Bayyurt, N. 2013. Ownership Effect on Bank's Performance: Multi Criteria Decision Making Approaches on Foreign and Domestic Turkish Banks. ProFedia-Social and Behavioral Sciences. 99: 919-928.

Berger, A. N \& Hannan, H. 1989. The Price-Concentration Relationship In Banking. The Review of Economics and Statistics. 71 (2): 291-299.

Berger, A. N., Clarke, G. R. G., Cull, R., Klapper, L \& Udell, G. F. 2005. Corporate Governance And Bank Performance: A Joint Analysis Of The Static, Selection, And Dynamic Effects Of Domestic, Foreign, And State Ownership. Journal of Banking and Finance. 29 (8): 2179-2221.

Berger, A. N., DeYoung, R., Genay, H \& Udell, G. F. 2000. Globalization of financial institutions: Evidence from cross-border banking performance. Brookings-Wharton Papers on Financial Services, 2000 (1): 23-120.

Binhadi. 1995. Financial Sector Deregulation, Banking Development, and Monetary Policy- the Indonesian Experience. Institute Bankir Indonesia, Jakarta.

Blomström, M., Kokko, A \& Zejan, M. 2000. Foreign Direct Investment: Firm and Host Country Strategies. St. Martin Press Inc., New York.

Bruno, V \& Hauswald, R. (2009). The Real Effect 
of Foreign Banks. World. Retrieved from http://ssrn.com/abstract=1344074.

Chen, S. H \& Liao, C. C. 2011. Are Foreign Banks More Profitable Than Domestic Banks? Home- And Host-Country Effects Of Banking Market Structure, Governance, And Supervision. Journal of Banking and Finance. 35 (4): 819-839.

Claessens, S. 2009. Competition In The Financial Sector: Overview Of Competition Policies. World Bank Research Observer.

Claessens, S., Demirgüç-Kunt, A \& Huizinga, H. 2001. How Does Foreign Entry Affect Domestic Banking Markets? Journal of Banking and Finance. 25 (5): 891-911.

Claessens, S \& Laeven, L. 2004. What Drives Bank Competition? Some International Evidence. Journal of Money, Credit and Banking. 36 (3): 563-583.

Crystal, J. S., Dages, B. G \& Goldberg, L. S. 2002. Has Foreign Bank Entry Led To Sounder Banks In Latin America?. Current Issues in Economics and Finance. 8 (1): 1-6.

Demirgüç-Kunt, A., Laeven, L \& Levine, R. 2004. Regulations, Market Structure, Institutions, And The Cost Of Financial Intermediation. Journal of Money, Credit and Banking. 36 (3): 593-622.

Deyoung, R \& Nolle, D. E. 1996. Foreign-Owned Banks in the United States: Earning Market Share or Buying It?. Journal of Money, Credit and Banking. 28 (4): 622.

Focarelli, D \& Pozzolo, A. 2005. Where Do Banks Expand Abroad? An Empirical Analysis Where Do Banks Expand Abroad? An Empirical Analysis. Source: The Journal of Business. 78 (6): 2435-2464.

Goldberg, L. S. 2007. Financial Sector FDI and Host Countries: New and Old Lessons. FRBNY Economic Policy Review. 3: 1-17.

Hamada, M. 2003. Transformation of the Financial Sector in Indonesia. IDE Research Paper. 6.

Haryanto, S. 2016. Profitability Identification Of National Banking Through Credit, Capital, Capital Structure, Efficiency, And Risk Level. Jurnal Dinamika Manajemen. 7 (1): 11-21.

Hasan, I \& Hunter, W. 1996. Efficiency of Japanese multinational banks in the United States. Research in Finance. JAI Press, Greenwich. 157173.

Herrero, A \& Simon, D. 2003. Financial FDI to
Emerging Economies from the Home Country's Perspective: a submitted for publication of the Literature. CGFS Publications, 22, Bank for International Settlements, Basel, Switzerland.

Hryckiewicz, A \& Kowalewski, O. 2010. Economic Determinates, Financial Crisis And Entry Modes Of Foreign Banks Into Emerging Markets. Emerging Markets Review. 11 (3): 205-228.

Hudgins, S. C \& Rose, P. S. 2010. Bank Management and Financial Services. New York: McGraw Hill.

Hymer, S. H. 1960. The International Operations of National Firms: A Study of Direct Foreign Investment. MITPress: Cambridge, MA.

Jeon, B. N., Olivero, M. P \& Wu, J. 2011. Do Foreign Banks Increase Competition? Evidence From Emerging Asian And Latin American Banking Markets. Journal of Banking and Finance. 35 (4): 856-875.

Jiang, C., Yao, S \& Feng, G. 2013. Bank Ownership, Privatization, And Performance: Evidence From A Transition Country. Journal of Banking and Finance. 37 (9): 3364-3372.

Lin, X \& Zhang, Y. 2009. Bank Ownership Reform And Bank Performance In China. Journal of Banking and Finance. 33 (1): 20-29.

Lu, C. H., Shen, C. H \& Wu, M. W. 2009. Impact of Foreign Bank Entry on the Performance of Chinese Banks. China \& World Economy. 17 (3): 102-121.

Manlagñit, M. C. 2011. The Economic Effects Of Foreign Bank Presence: Evidence From The Philippines. Journal of International Money and Finance. 30: 1180-1194.

Mester, L. J. 1996. A Study Of Bank Efficiency Taking Into Account Risk-Preferences. Journal of Banking and Finance. 20 (6): 1025-1045.

Micco, A., Panizza, U \& Yanez, M. 2007. Bank Ownership And Performance. Does Politics Matter? Journal of Banking and Finance. 31 (1): 219-241.

Morgan, D. P \& Strahan, P. E. 2004. Foreign Bank Entry And Business Volatility: Evidence From US States And Other Countries. Banking Market Structure and Monetary Policy, Central Bank of Chile, Santiago.

Naaborg, I., Scholtens, B., De Haan, J., Bol, H \& De Haas, R. 2004. How Important Are Foreign Banks In The Financial Development Of 
Amarilla Hapsari \& Rofikoh Rokhim / Forign Ownership and Bank Performance:...

European Transition Countries. Journal of Emerging Market Finance. 3: 99-123.

Nagano, M. 2016. The Bank-Firm Relationship During Economic Transition: The Impacts On Bank Performance In Emerging Economies. Emerging Markets Review. 28: 117 - 139

Nasution, A. 1996. Financial Institutions and Policies in Indonesia. Institute of Southeast Asian Studies, Singapore.

Northcott, C. 2004. Competition In Banking: A Review Of The Literature. Working Paper, Bank of Canada, 2004-24.

Okuda, H \& Rungsomboon, S. 2006. Comparative Cost Study Of Foreign And Thai Domestic Banks In 1990-2002: Its Policy Implications For A Desirable Banking Industry Structure. Journal of Asian Economics. 17 (4): 714-737.

Olievero, M. P., Li, Y \& Jeon, B. N. 2009. Consolidation In Banking And The Lending Channel Of Monetary Transmission: Evidence From Asia And Latin America. Working Paper, LeBow College of Business, Drexel University.

Rao, A. 2005. Cost Frontier Efficiency And RiskReturn Analysis In An Emerging Market. International Review of Financial Analysis. 14 (3): 283-303.

Rokhim, R \& Susanto, A. P. 2013. The Increase Of Foreign Ownership And Its Impact On The Performance, Competition And Risk In The Indonesian Banking Industry. Asian Journal of Business and Accounting. 6 (2): 139-155.

Sato, Y. 2005. Bank Restructuring and Financial Institution Reform in Indonesia. The Developing Economies. XLIII (1): 91-120.

Thi, N \& Vencappa, D. 2007. Does the Entry Mode of Foreign Banks Matter for Bank Efficiency?
Evidence from Czech Republic, Hungary, and Poland. Manuscript, Nottingham University Business School, University of Nottingham, United Kingdom.

Unite, A \& Sullivan, M. 2003. The Effect Of Foreign Entry And Ownership Structure On The Philippines Domestic Banking Market. Journal of Banking and Finance. 27: 23232345.

Wardhana, A. 1995. Financial Reform: Achievement, Problems, And Prospects, In Indonesia Assessment 1994 Finance As A Key Sector In Indonesia's Development. Institute of Southeast Asian Studies, Singapore.

Williams, J \& Nguyen, N. 2005. Financial Liberalisation, Crisis, And Restructuring: A Comparative Study Of Bank Performance And Bank Governance In South East Asia. Journal of Banking and Finance. 29: 2119-2154.

World Bank. 1986. The Philippines a Framework for Economic Recovery. The World Bank, Washington DC.

World Bank. 2006. Global Development Finance. The World Bank, Washington DC.

Woo, G \& Nasution. 1994. Macroeconomic policies, Crisis, and Long-Term Growth in Indonesia. The World Bank, Washington DC.

Wu, J., Leon, B. N \& Luca, A. 2010. Foreign Bank Penetration, Resource Allocation And Economic Growth: Evidence From Emerging Economies. Journal of Economic Integration. 25 (1): 166-192.

Yildirim, H. S \& Philippatos, G. C. 2007. Restructuring, Consolidation And Competition In Latin American Banking Markets. Journal of Banking and Finance. 31 (3): 629-639. 